\title{
WIRAUSAHA JAMUR TIRAM PUTIH BERBASIS TECHNOPRENEUR SEBAGAI SUMBER WIRAUSAHA BARU DALAM PEMANFAATAN LIMBAH KAYU SERBUK GERGAJI JORONG TARATAK NAGARI NANAM
}

\section{BASED ON TECHNOPRENEUR FUNGUS OUR WHITE ENTREPRENEURS AS A SOURCE OF NEW BUSINESSES IN GETTING WOOD WOOD (POWDER SAWS) IN JORONG TARATAK PAUH NAGARI SUNGAI NANAM}

\author{
L Hasan'1a, S Yonaldi ${ }^{1}$ N Suryani \\ 'Program Studi Manajemen, Fakultas Ekonomi, Universitas Tamansiswa Padang. \\ aKorespondensi: Lenny Hasan; E-mail: lenihasan@gmail.com \\ (Diterima: 09-09-2019; Ditelaah: 19-09-2019; Disetujui: 18-01-2020)
}

\begin{abstract}
Jorong Taratak Pauah Nagari Sungai Nanam has good potential in utilizing the potential of sawdust waste to be used as a media for growing white oyster mushrooms, which will later be used as raw materials for high-value food preparations. Partners as the target of the programming community are constrained in utilizing the potential caused by several problems, including not understanding how to utilize sawdust waste, do not yet have the ability and good knowledge in terms of management, and do not have the ability and knowledge in marketing. The objectives of the PPM program are; the community understands the use of sawdust waste, the community has business management knowledge, and has knowledge in the field of marketing. The PPM program methods are; 1 ) Counseling, 2) Pilot production, 3) Business management training, 4) Marketing training, 5) Assistance. The results of the PPM Entrepreneurship activities based on Technopreneur White Oysters as a New Source of Entrepreneurship in the Utilization of Wood Waste (Sawdust) in Jorong Taratak Pauh Nagari Sungai Nanam, are; 1) the target community has the ability to cultivate oyster mushrooms, 2) the community is able to process white oyster mushrooms into processed high-value foods such as oyster mushroom rendang, oyster mushroom jerky, and oyster mushroom crispy), 3) communities have marketing capabilities, 4) the formation of business groups by the name of Mushroom Solidarity Group. The output of this activity is the development of community business groups in the cultivation of white oyster mushroom, thereby increasing family income.
\end{abstract}

Keywords: Oyster mushroom, sawdust, technopreneur.

\section{ABSTRAK}

Jorong Taratak Pauah Nagari Sungai nanam memiliki potensi yang baik dalam memanfaatkan potensi limbah serbuk gergaji untuk dijadikan media tanam jamur tiram putih yang nantinya sebagai bahan baku untuk olahan makanan yang bernilai tinggi. Mitra sebagai masyarakat sasaran program terkendala dalam pemanfaatan potensi tersebut yang dikarenakan oleh beberapa permasalahan, diantaranya adalah tidak memahami bagaimana memanfaatkan limbah serbuk gergaji, belum memiliki kemampuan dan pengetahuan yang baik dalam hal manajemen pengelolaan, dan tidak memiliki kemampuan dan pengetahuan dalam bidang pemasaran. Tujuan program PPM ini adalah; masyarakat memahami pemanfaatan limbah serbuk gergaji, Masyarakat memiliki pengetahuan pengelolaan usaha,, dan memiliki pengetahuan dalam bidang pemasaran. Metode program PPM ini adalah; Penyuluhan, Percontohan produksi, Pelatihan manajemen usaha, Pelatihan Pemasaran, Pendampingan. Hasil Kegiatan PPM Wirausaha Jamur Tiram Putih berbasis Technopreneur 
Sebagai Sumber Wirausaha Baru Dalam Pemanfaatan Limbah Kayu (Serbuk Gergaji) di Jorong Taratak Pauh Nagari Sungai Nanam, adalah ; 1) masyarakat sasaran memiliki kemampuan budidaya jamur tiram, 2) masyarakat mampu mengolah jamur tiram putih menjadi olahan makanan bernilai tinggi seperti rendang jamur tiram, dendeng jamur tiram, dan crishpy jamur tiram), 3) masyarakat memiliki kemampuan pemasaran, 4) terbentuknya kelompok usaha dengan nama Jamur soladirity Group. Keluaran dari kegiatan ini adalah berkembangnya kelompok usaha masyarakat dalam usaha budidaya jamur tiram putih, sehingga meningkatkan pendapatan keluarga.

Kata kunci: Jamur tiram, serbuk gergaji, technopreneur.

Hasan, L., Yonaldi, S., \& Novelisa, S. (2019).Wirausaha Jamur Tiram Putih Technopreneur Sebagai Sumber Wirausaha Baru Dalam Pemanfaatan Limbah Kayu (Serbuk Gergaji) di Jorong Taratak Pauh Nagari Nanam. Jurnal Qardhul Hasan : Media Pengabdian kepada Masyarakat, 6(1), 57-65.

\section{PENDAHULUAN}

\section{Latar Belakang Masalah}

Provinsi Sumatera Barat memiliki 160 Kacamatan, 507 Pemerintahan Nagari yang tersebar pada 12 Daerah Kabupaten serta 62 Nagari yang terdapat di lingkungan Daerah Kota, 41 Pemerintahan Desa (Khusus di Kab. Mentawai), serta 379 Pemerintah Kelurahan. Kecamatan Lembah Gumanti Kab. Solok terdiri dari 4 Nagari dan 68 Korong (Dusun). Nagari-nagari yang ada di kecamatan Lembah Gumanti adalah Nagari Sungai Nanam, Alahan Panjang , Salimpat, dan Aie Dingin. Nagari Sungai Nanam merupakan desa yang mayoritas penduduknya bertani. Luas lahan pertanian di Nagari Sungai Nanam 417 ha, yang berarti berpotensi untuk menghasilkan budidaya jamur tiram putih. Program pemanfaatan limbah serbuk gergaji kayu sebagai sumber wirausaha baru dalam menghasilkan produk makanan berkualitas berbahan baku jamur tiram putih di Jorong Taratak Pauh Nagari Sungai Nanam Kabupaten Solok berbasis technopreneur dipilih dengan pertimbangan diantaranya peluang usaha budidaya jamur tiram di Jorong Taratak Pauah Nagari Sungai Nanam sangat cocok karena didukung oleh suhu dan potensi lahan, selain itu modal yang diperlukan tidak terlalu besar dengan harga jual yang cukup tinggi, dan dapat dipanen setiap hari di saat jamur telah berproduksi.
Kewirausahaan dengan konsep technopreneur merupakan suatu proses kreativitas dan inovasi untuk menghasilkan nilai tambah bagi produk yang bermanfaat bagi masyarakat dan mendatangkan kemakmuran bagi wirausahawan dalam hal ini adalah pengolahan limbah serbuk gergaji menjadi bahan baku untuk menghasilkan jamur tiram putih. Dengan menumbuhkembangkan wirausaha pada petani miskin dan pembekalan yang cukup, maka dapat meningkatkan sumberdaya ekonomi, sehingga kesejahteraannya meningkat. Jumlah penduduk Indonesia pada tahun 2025 diperkirakan mencapai 273,7 juta jiwa. Demikian dikatakan Menteri Negara Perencanaan Pembangunan/Kepala Bappenas saat menyebutkan proyeksi penduduk Indonesia tahun 2000-2025 (Kompas, 3/8/2005). Dengan jumlah penduduk sebesar itu Indonesia merupakan pasar yang luar biasa besar. Potensi ini merupakan peluang bagi masyarakat miskin untuk memulai wirausaha makanan, guna memenuhi kebutuhan protein masyarakat. Penelitian yang dilakukan di Perguruan Tinggi sering kali hanya berakhir sebagai arsip lembaga. Penerapan langsung dari hasil penelitian di tengah masyarakat terutama masyarakat miskin, akan mempercepat implementasi hasil penelitian tersebut. Kegiatan Pengabdian ini bertujuan untuk mencari nilai manfaat terbaik dari potensi pertanian lokal dengan teknologi tepat guna, sehingga meningkatkan pendapatan masyarakat petani miskin 
karena usaha jamur tiram putih merupakan usaha baru yang dapat memberikan hasil berkelanjutan, dapat dijadikan peluang usaha yang cukup potensial. Selain itu, limbah jamur merupakan makanan ternak alternatif yang cukup potensial untuk digunakan.

\section{Fokus Permasalahan}

Jorong Taratak Pauah Nagari Sungai Nanam Kecamatan Lembah Gumanti Kabupaten Solok merupakan daerah yang memiliki jumlah usaha pengrajin kayu yang cukup banyak.berdasarkan observasi pengusul ada sekitar 20 tempat usaha pengolahan kayu, namun serbuk gergaji ini tidak dimanfaatkan sebagai sumber wirausaha dalam menghasilkan jamur tiram putih. Adapun permasalahan mitra adalah sebagai berikut:

Permasalahan limbah serbuk gergaji Limbah serbuk gergaji yang dihasilkan oleh proses eksploitasi/pembalakan maupun pengolahan kayu menimbulkan masalah dalam hal penanganannya yang selama ini dibiarkan membusuk, ditumpuk dan dibakar sehingga merusak kebersihan dan kenyamanan lingkungan dan pada akhirnya akan menjadi sumber penyakit pada masyarakat disekitarnya. 2. Permasalahan dalam bidang manajemen. Masyarakat Jorong Taratak Pauh Nagari Sungai Nanam Tabel 1. Tabel Permasalahan sebagai sasaran program tidak memahami bagaimana memanfaatkan limbah serbuk gergaji sebagai bahan baku untuk pembuatan jamur tiram putih dan mereka juga tidak memiliki kemampuan dalam memproduksi jamur tiram putih menjadi kuliner yang menarik dan disukai oleh konsumen. 3. Permasalahan dalam bidang manajemen 4. Masyarakat sasaran belum memiliki kemampuan dan pengetahuan yang baik dalam hal manajemen pengelolaan usaha yang baik, sehingga usaha yang mereka kelola stagnan dan tidak bisa berkembang dengan baik. 5 . Permasalahan pemasaran 6. Masyarakat sasaran tidak memiliki kemampuan dan pengetahuan dalam bidang pemasaran, sehingga potensi pasar tidak bisa dimanfaatkan sebaik mungkin.

\section{Pemecahan Masalah}

Berdasarkan persoalan dan potensi yang ada pada mitra sasaran tersebut, maka akan dilaksanakan program pemanfaatan limbah serbuk gergaji kayu sebagai sumber wirausaha baru dalam menghasilkan produk makanan berkualitas berbahan baku jamur tiram putih di Jorong Taratak Pauh Nagari Sungai Nanam Kabupaten Solok berbasis technopreneur. Berikut solusi, luaran dan indikator capaian program.

\begin{tabular}{|l|l|l|l|}
\hline No & Solusi & Luaran & $\begin{array}{l}\text { Indikator } \\
\text { Capaian }\end{array}$ \\
\hline \multicolumn{2}{|l|}{ a. Permasalahan limbah serbuk gergaji } \\
\hline 1 & Penyuluhan & $\begin{array}{l}\text { Munculnya kesadaran dari para petani di nagari } \\
\text { Sungai Nanam bahwa budidaya jamur tiram ini } \\
\text { adalah salah satu bentuk pemanfaatan limbah } \\
\text { serbuk gergaji sebagai bahan baku utama } \\
\text { pembuatan media tanam (bag log) jamur tiram } \\
\text { sehingga limbah serbuk gergaji dapat } \\
\text { dimanfaatkan dan memiliki nilai ekonomi yang } \\
\text { lebih tinggi }\end{array}$ & \begin{tabular}{l} 
\\
\hline
\end{tabular} \\
\hline b. Permasalahan dalam bidang produksi \\
\hline
\end{tabular}




\begin{tabular}{|c|c|c|c|}
\hline 2 & $\begin{array}{l}\text { Pelatihan } \\
\text { dan } \\
\text { Pembekalan }\end{array}$ & $\begin{array}{l}\text { 1. Masyarakat sasaran memiliki pengetahuan } \\
\text { secara teori dalam pengolahan serbuk gergaji } \\
\text { menjadi media tanam jamur tiram putih } \\
\text { 2. Masyarakat sasaran memiliki kemampuan } \\
\text { memproduksi jamur tiram putih menjadi } \\
\text { produk yang bernilai ekonomi nseperti home } \\
\text { industry Jamur Crispy, oseng oseng, rendang } \\
\text { jamur dan lainnya. }\end{array}$ & Penerapan \\
\hline
\end{tabular}

\begin{tabular}{|c|c|c|c|}
\hline 3 & Percontohan & $\begin{array}{l}\text { 1. Masyarakat sasaran sudah memeliki skill dan } \\
\text { ketrampilan pengolahan serbuk gergaji } \\
\text { menjadi media tanam jamur tiram putih } \\
\text { 2. Msayarakat sasaran memiliki skill dan } \\
\text { ketrampilan memproduksi jamur tiram putih } \\
\text { menjadi produk yang bernilai ekonomi } \\
\text { nseperti home industry Jamur Crispy, oseng } \\
\text { oseng, rendang jamur dan lainnya. }\end{array}$ & Produk \\
\hline \multicolumn{4}{|c|}{ c. Permasalahan pengelolaan manajemen usaha } \\
\hline 4 & $\begin{array}{l}\text { Pelatihan } \\
\text { Manajem } \\
\text { en Usaha }\end{array}$ & $\begin{array}{l}\text { Munculnya pemahaman manajemen usaha yang baik } \\
\text { sebagai bekal untuk meningkatkan produksi dan } \\
\text { pemasaran produk }\end{array}$ & Penerapan \\
\hline \multicolumn{4}{|c|}{ d. Permasalahan Pemasaran } \\
\hline 5 & $\begin{array}{l}\text { Pelatihan } \\
\text { Pemasar } \\
\text { an }\end{array}$ & $\begin{array}{l}\text { Masyarakat sasaran memiliki pengetahuan dan } \\
\text { kemampuan tentang teknik pemasaran yang baik, } \\
\text { seperti pemanfaatan teknologi digital pada market } \\
\text { place business dengan model ecommerce }\end{array}$ & Penerapan \\
\hline
\end{tabular}

kewirausahaan bagi pelaku usaha pemula;

\section{MATERI DAN METODE}

Dalam rangka menumbuhkan wirausaha baru di kalangan petani dalam pemanfaatan limbah serbuk gergaji kayu sebagai sumber wirausaha baru dalam menghasilkan produk makanan berkualitas berbahan baku jamur tiram putih di Jorong Taratak Pauh Nagari Sungai Nanam Kabupaten Solok berbasis technopreneur akan dilaksanakan dengan pendekatan sebagai berikut: Penyuluhan; pelatihan dan percontohan produksi; Pelatihan manajemen usaha; pelatihan pemasaran; pendampingan.

\section{Penyuluhan}

Penyuluhan dilakukan dengan motedo pembelajaran orang dewasa, dimana semua peserta terlibat aktif selama penyuluhan berlangsung.Materi penyuluhan: Materi
Potensi pengolahan limbah serbuk gergaji menjadi media tanam untuk jamur tiram putih; Jamur tiram putih sebagai sumber wirausaha baru dalam menghasilkan produk makanan yang berkualitas tinggi; Masyarakat sasaran berperan dalam penyiapan tempat, pendistribusian undangan pelaksanaan kegiatan penyuluhan.

\section{Pelatihan dan Percontohan Produksi}

Pelatihan produksi ini dilakukan dengan metode: Peserta 50 orang yang terbagi m,enjadi kelompok; dilaksanakan selama 2 hari.

Materi hari pertama: Penyampaian materi-materi secara teori tentang pembuatan media tumbuh jamur tiram dengan pemanfaatan limbah serbuk gergaji;penyampaian materi tentang 
budidaya jamur tiram; penyampaian materi tentang pemanfaatan jamur tiram sebagai bahan baku makanan berkualitas tinggi.; diskusi kelompok.

Hari kedua: Praktek lapangan untuk pembuatan media jamur dari limbah jamur tiram;Praktek pengolahan jamur menjadi berbagai macam makanan, rendang jamur, jamur crispy, oseng orang dan bakso jamur; Pembuatan rencana tindak lanjut (RKTL): Bahan dan Peralatan yang disiapkan untuk pembuatan media tanam jamur tiram, Bahan dan peralatan yang disiapkan untuk pembuatan media tanam jamur tiram:

Serbuk Kayu bahan ini merupakan bahan dasar pembuatan media tanam (baglog). Serbuk Kayu mengandung berbagai zat di dalamnya yang dapat memacu pertumbuhan atau sebaliknya. Zat-Zat yang dibutuhkan Jamur Untuk Tumbuh Yaitu Karbohidrat serat lignin. Sedangkan Zat yang dapat menghambat pertumbuhan yaitu zat metabolit sekunder atau yang umum dikenal pohom tidak bergetah dan atsiri. Dengan demikian serbuk kayu yang digunakan hendaknya dari pohon tidak bergetah seperti albasia, randu, rante dan lain- lain.

Kapur merupakan bahan baku sebagai sumber kalsium (Ca) dan berguna untuk mengatur tingkat keasaman $(\mathrm{pH})$ media. Kapur yang digunakan yaitu kapur pertanian $\left(\mathrm{CaCO}_{3}\right)$. Kandungan kalsium dan karbonnya sangat dibutuhkan bagi pertumbuhan jamur dan sebagai penyumbang nutrisi pada saat jamur dikonsumsi.

Bekatul merupakan hasil sisa dari penggilingan padi apabila diamati bekatul terdiri dari bubuk dan butiran kecil akibat dari pengupasan kulit padi, selain itu mengandung serbuk kulit padi. Bahan ini telah umum digunakan pada industri peternakan sebagai pakan,

Gips atau $\mathrm{CaSO}_{4}$ digunakan sebagai sumber kalsium (Ca) dan berguna untuk memperkokoh media baglog. Dalam keadaan kokoh media tidak akan cepat rusak. Namun penggunaan gips disebutsebut tidak organik dan tidak sehat mungkin karena mengandung senyawa $\mathrm{SO}_{4}$, oleh karena itu gips mulai ditinggalkan oleh petani jamur.

Pupuk Pemberian pupuk juga merupakan pilihan. Pupuk yang biasa diberikan yaitu urea dan SP-36. pemberian pupuk dimaksudkan sebagai nutrisi pertumbuhan jamur dan dapat mempercepat pemanenan. Selain itu ukuran rata-rata jamur yang dihasilkan lebih besar.

Bahan peralatan yang di siapkan untuk pengolakan jamur tiram putih menjadi beragamolahan makanan. Bahan dan peralatan yang disiapkan untuk pengolahan jamur tiram putih menjadi berbagai olahan makanan: Bahan yang digunakan 500 gr jamur putih atau jamur tiram, 100 gr tepung terigu sesuai pilihan air putih matang, $2 \mathrm{sdm}$ garam, 1 sdt merica, 2 siung bawang putih, minyak goreng secukupnya, bumbu perasa seperti rasa pedas, keju, barbeque, dan sebagainya (tambahan). Metode percontohan; bersihkan dan potong jamur sesuai pilihan. Usahakan tidak memotong jamur terlalu kecil, buka bawang putih, geprek hingga hancur. Haluskan tuang air putih ke mangkok. Campurkan garam, merica, bawang putih yang telah dihaluskan ke dalam air. Masukan jamur yang telah dipotong sesuai bagian ke dalam air berisi bumbu. Diamkan kira-kira 5 menit. Angkat jamur dari air, tiriskan. Balur jamur berubah warna kecoklatan. Angkat dan tiriskan. Masukan jamur ke dalam wadah tertutup. Berikan taburan tepung bumbu. Kocok jamur segingga bumbu merata. Tuangkan dalam piring.

\section{Tahapan Pelatihan Manajemen Usaha dan Pelatihan Pemasaran}

Pelatihan ini ditujukan untuk memberikan muatan kapasitas tentang pengelolaan usaha yang sesuai dengan konsep dan metode ilmu manajemen. Peserta 50 orang, serta dilaksanakan dengan empat sesi materi selama 1 hari, Materi Konsep dasar Ilmu manajemen bisnis, rancangan usaha 
(Busuness Plan), sistem pembukuan sederhana dan pembuatan laporan keuangan, teknik dan metode pemasaran dengan menggunakan teknologi digital (Ecommerce)

\section{Tahapan pendapingan}

Tahapan pendampingan merupakan kegiatan yang dilaksanakan pasca kegiatan dengan tetap memberikan pendampingan manajemen usaha dan pemasaran produk. Kegiatan pendampingan ini akan dilaksanakan secara berkala oleh dosen pengusul dan mahasiswa yang dilibatkan dalam kegiatan. Program program yang akan dilaksanakan diharapkan dapat dilanjutkan oleh masyarakat dengan tetap melakukan kerjasama dengan mitra . untuk jangka panjang seluruh program pemanfaatan limbah serbuk gergaji kayu sebagai sumber wirausaha baru dalam menghasilkan produk makanan berkualitas berbahan bau jamur tiram putih di jorong taratak pauah negri sungai nanam Kabupaten Solok berbasis tecnopreneur ini akan dilakuakan kerjasama dengan pemerintahan daerah untuk dilanjutkan sebagai program pemerintahan daerah.

Untuk menjaga dan mengelola kegiatan program pemanfaatan limbah serbuk gergaji kayu sebagai sumber wirausaha baru dalam menghasilkan produk pemanfaatan limbah serbuk kayu sebagai sumber wirausaha baru dalam menghasilkan produk makanan berkualitas berbahan baku jamur tiram putih dijorok taratak pauh nagari nanam Kabupaten Solok berbasis tecnopreneur maka akan dilakukan penyusunan usaha kelompok.

\section{HASIL DAN PEMBAHASAN}

Hasil capaian Pembentukan Kelompok Usaha Jamur Tiram. Pada kegiatan koordinasi dan sosialisasi program jamur tiram berbasis tecnopreneur sebagai sumber wirausaha baru dalam pemanfatan limbah kayu ( serbuk gergaji ) di jorok taratak pauh nagari sungai nanam dilaksanakan kegiatan pembentukan kelompok usaha jamur tiram sebagai kelompok masyarakat sasaran program PKM.

Gambar 1. Foto Kegiatan pembentukan kelompok usaha jamur tiram.

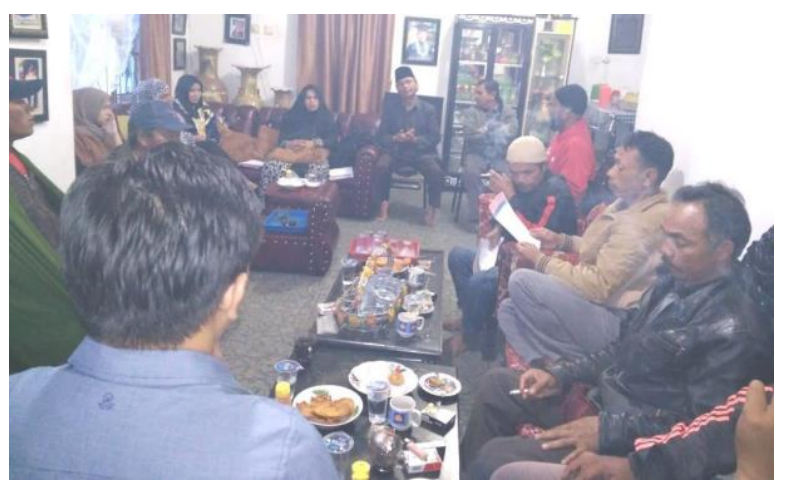

Tujuan dari pembentukan kelompok ini adalah untuk mengorganisir masyarakat dalam pelaksanaan kegiatan PKM dan untuk memastikan pasca pelaksanaan program PPM masyarakat dapat melanjutkan program ini dengan sebaik-baiknya. 


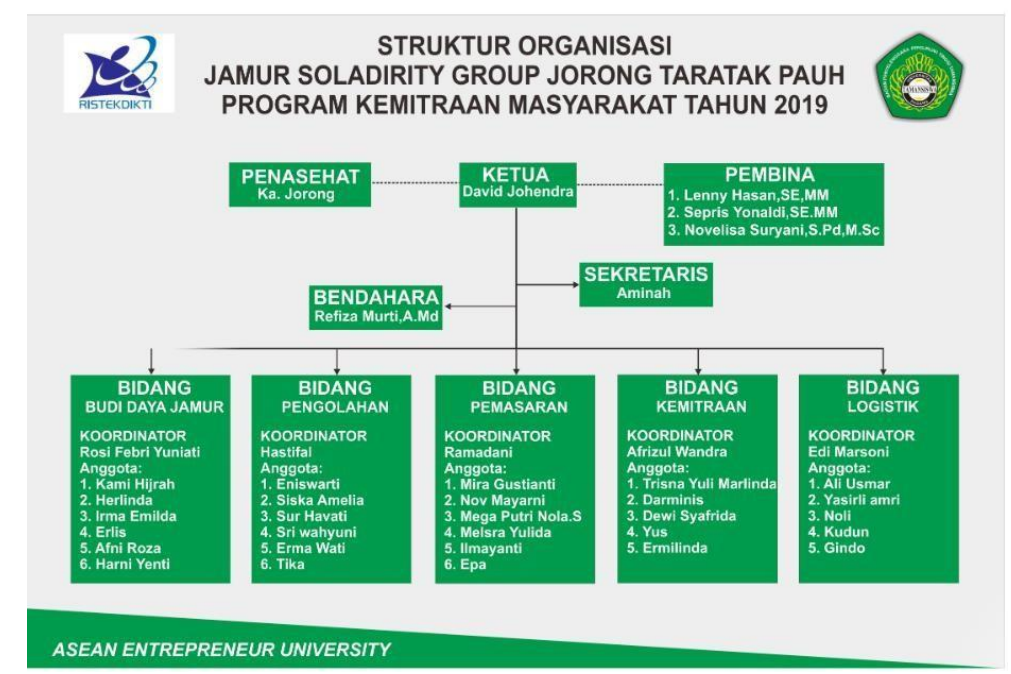

Gambar 2. Struktur Jamur Soladirity Group (JSG) Jorong Taratak Pauh.

Gambar 3. Palang Merek Prganisasi Jamur soladirity Group (JSG) jorong Taratak Pauh.

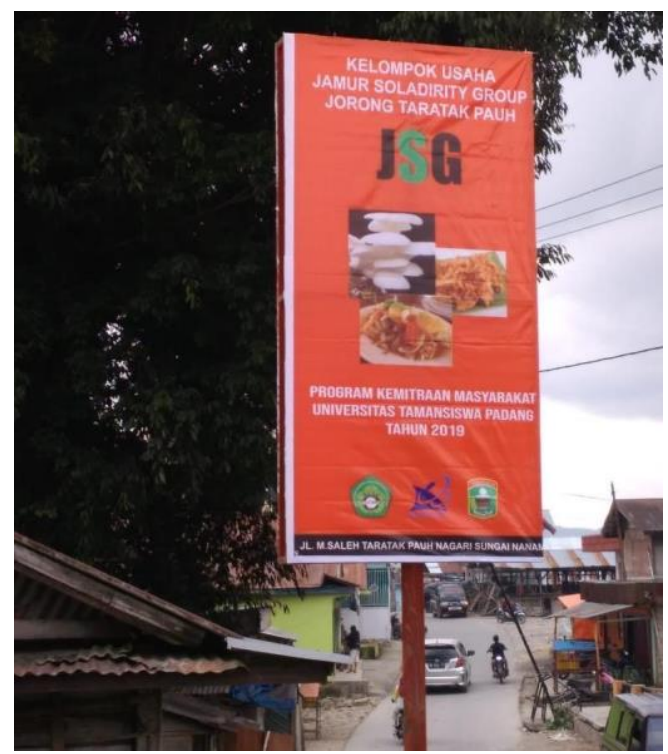

\section{Penyuluhan}

Pada hari minggu 23 Juni 2019 bertempatan di jorong taratak pauh nagari sungai nanam dilaksanakan kegitan penyuluhan yang dilaksanakan dengan jumlah peserta 50 orang (absensi terlampir) kegiatan penyuluhan kewirausahaan dilakukan dengan metode pembelajaran orang dewasa, dimana semua peserta terlibat aktif selama penyuluhan berlangsung. Masyarakat sasaran berperan dalam menyiapkan tempat, pendistribusian undangan pelaksanaan kegiatan penyuluhan: materi penyuluhan; materi kewirausahaan bagi pelaku usaha pemula; potensi pengolahan limbah serbuk gergaji menjadi media tanam untuk jamur tiram putih; jamur tiram putih sebagai sumber wirausaha baru dalam menghasilkan produk makanan yang berkualitas tinggi

Capaian dari pelaksanaan kegiatan penyuluhan kewirausahaan ini adalah: masyarakat memahami pentingnya berwirausaha untuk meningkatkan penghasilan rumah tangga dan berdampak pada hidup lebih sejahtera; masyarakat memahami bahwa serbuk gergaji merupakan potensi lokal atau bahan baku yang nilai ekonomi yang tinggi untuk bahan baku utama dalam kegiatan budidaya jamur tiram putih dan didukung dengan geografis atau udara yang dingin di jorong taratak pauh.

Masyarakat juga menyadari, bahwa jamur tiram putih merupakan makanan berpotensi pengganti daging yang dimiliki kandungan gizi yang baik bagi tubuh.

Gambar 4. Kegiatan Penyuluhan Kewirausahaan

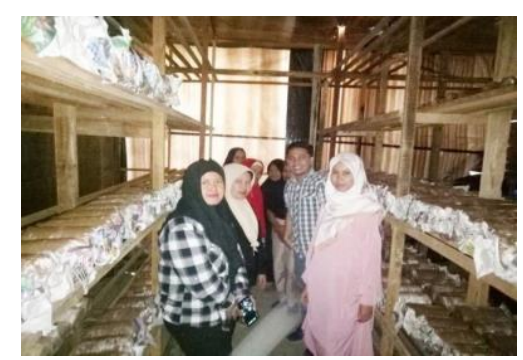




\section{Pembuatan rumah jamur}

Dalam mendukung pelaksanaan kegiatan PPM wirausaha Jamur Tiram Putih berbasis Technopreneur sebagai sumber wirausaha baru dalam pemanfaatan limbah kayu (serbuk gergaji) di Jorok Taratak Pauh Nagari Nanam dilaksanakan pembuatan pembuatan rumah jamur yang dilaksanakan pada tanggal 1s/d Juli 2019 yang bertempatan di jalan M Saleh Jorong taratak Pauh.

Gambar 5. Pembuatan Rumah Jamur

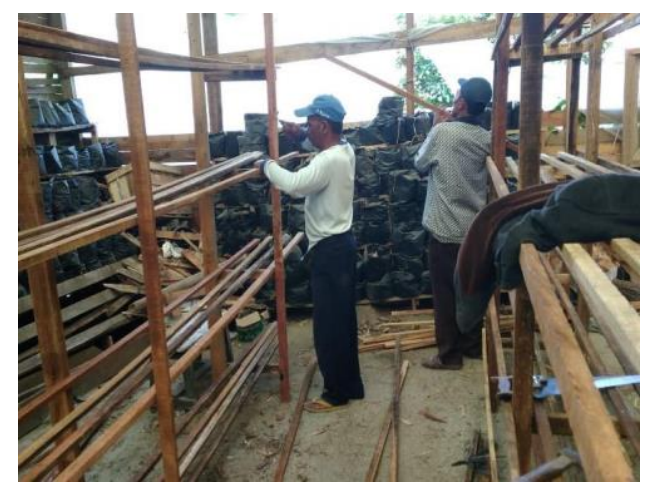

Gambar 6. Rumah Jamnur dan Foto Tim PPM

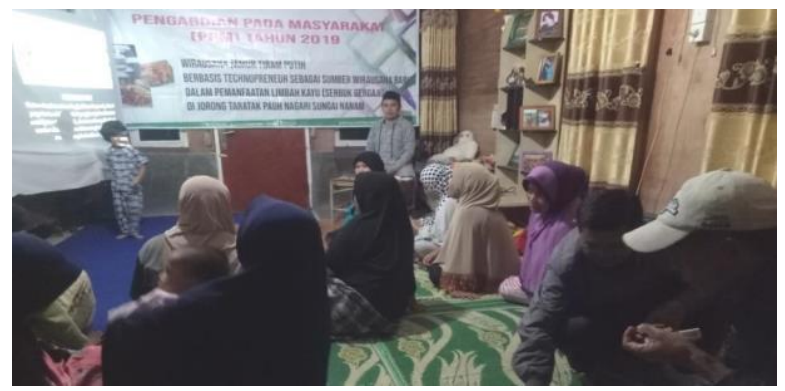

\section{Pelatihan dan percontohan Produksi}

Kegiatan pelatihan dan percontohan produksi budidaya jamur tiram putih dilaksanakan pada hari minggu 7 Juli 2019 bertempatan di secretariat kelompok jamur tiram JSG Jl. Masel Jorong Taraktak Pauh. Peltihan prosuksi dan pecontohan ini di ikuti sebanyak 50 Orang (absensi terlampir)

Materi kegiatan ini adalah penyampaian materi- materi secarateori tentang pembuatan media tumbuh jamur tiram dengan pemanfaatn limbah serbuk gergaji. Penyampaian materi tentang budidaya jamur tiram. Penyampaian materi tentang pemanfaatan jamur tiram sebagai bahan baku makanan berkualitan tinggi; praktek lapanghan untuk pembuatan media jamur tiram dari limbah jamur tiram.

Output dari kegiatan ini adalah masyarakat sasaran sudah memiliki skill dan keterampilan pengelilaan serbuk gargaji menjadi media tanam jamur tiram putih.

\section{Pelatihan produksi dan Pengolahan Jamur Tiram “}

Tahapan berikut pada program PPM wisatawan jamur tiram putih berbasis technopreneur sebagai sumber wirausaha baru dalam pemanfaatan limbah kayu (serbuk gergaji) di Jorok Taratak Pauh Nagari Sungai Nanam adalah Melaksanakan kegiatan pelatihan pengelolaan jamur tiram sebagai bahan makanan olahan jadi. Adapun olahan makanan yang dijadikan prioritas dan program ini adalah: rending jamur tiram; dendeng jamur tiram; crisphy jamur tiram.

Kegiatan pelatihan pengolahan jamur tiram menjadi olahan makanan ini dengan metode membentuk 3 kelompok sesuai dengan 3 produk yang dijadikan prioritas pada program ini adalah : Rendanf jamur tiram; dendeng jamur tiram; crisphy jamur tiram.

Kegiatan pelatihan pengolahan jamur tiram menjadi olahan ini dengan metode membentuk 3 kelompok sesuai dengan produk yang dijadikan prioritas. Bentuk adalah gambar kegiatan pelatihan tersebut.

Gambar 7. Proses pengelohan dan pengemasan Dengdeng Jamur. Tiram

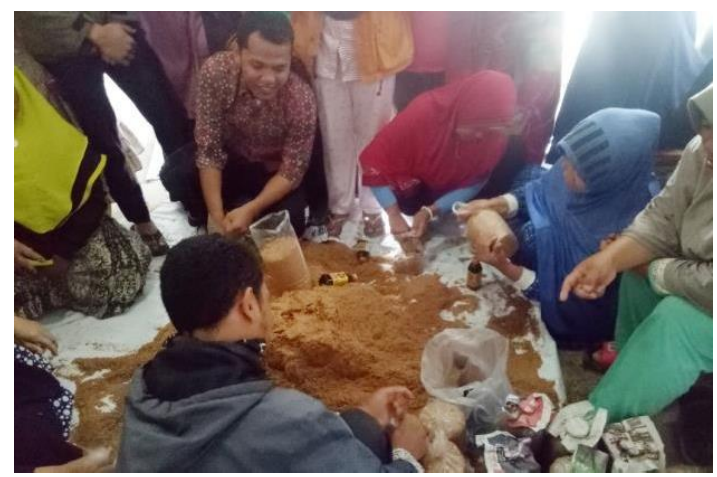




\section{Pendampingan}

Kegiatan pendampingan pasca produksi makanan olahan jamur putih tetap dilakukan oleh tim program PPM. Adapun beberapa kegiatan pendampungan yang dilakuakan adalah dalam hal kelembagaan organisasi kelompok, pengelolaan administrasi dan juga dalam hal pemasaran produk. Berikut adalah beberapa kegiatan pemasaran yang dilakuakan.

\section{KESIMPULAN}

Program pemanfaatan limbah serbuk gergaji kayu sumber wirausaha baru dalam menghasilkan produk makanan berkualitas berbahan baku jamur tiram putih di jorong Taratak Pauh Nagari Sugai Nanam Kabupaten Solok Berbasis Technopreneur dipilih dengan pertimbanagn diantaranya peluangan usaha budi daya jamur tiram di Jorong Taratak Pauah Nagari sunagi Nanam sangat cocok karena didukung oleh suhu dan potensi lahan, selain itu modal yang diperlukan tidak terlalu besar dengan harga jual yang cukup tinggi dan dapat dipanen setiap hari telah berproduksi.

Kelompok masyarakat sebagai sasaran program PPM wirausaha Jamur tiram putih berbasis technopreneur. Sebagai sumber wirausaha baru dalam pemanfaatan limbah kayu ( serbuk gergaji) di Jorong Tratak Pauh Nagari Sungai Nanam yang tergabung dalam kelompok Jamyr tiram soladirity Group (JSG) sangat berpotensi untuk dapat dilaksanakan semua anggota kelompok dapat mengikuti kegiatan dengan baik.

Adapun yang menjadi saran dari kegiatan yang berjalan di tahap 70\% ini,yaitu meningkatkan partisipasi laki-laki dalam kegiatan ini, karena kegiatan yang berjalan ditahan 70 \& ini, yaitu meningkatkan partisipasi laki-laki dalam kegiatan ini, karena kegiatan ini dikomunikasi oleh perempuan atau ibu-ibu rumah tangga, dan pemerintah setempat lebih meningkatkan fasilitasi dalam pelaksanaan program.

\section{UCAPAN TERIMAKASIH}

Puji syukur kehadirat Nya, akhirnya artikel ini dapat penulis selesaikan dengan mengikuti aturan yang ada. artikel ini merupakan hasil kegiatan Pengabdian Pada Masyarakat (PPM) di Jorong Taratak Pauh Nagari Sungai Nanam Kabupaten Solok dengan judul Wirausaha Jamur Tiram Putih berbasis Technopreneur Sebagai Sumber Wirausaha Baru Dalam Pemanfaatan Limbah Kayu (Serbuk Gergaji) di Jorong Taratak Pauh Nagari Sungai Nanam Ucapan terima kasih penulis ucapkan kepada Lembaga Layanan Dikti Wilayah X yang telah menyalurkan dana Hibah PPM ini dari DIPA Direktorat Riset dan Pengabdian Masyarakat Direktorat Jenderal Penguatan Riset dan Pengembangan Kementerian Riset, Teknologi, dan Pendidikan Tinggi sesuai dengan Kontrak Program Pengabdian Masyarakat Tahun Anggaran 2019 antara Direktorat Riset dan Pengabdian Masyarakat dengan Kopertis Wilayah X Nomor: 114/SP2H/PPM/DRPM/2019.

\section{DAFTAR PUSTAKA}

Parjino. Dkk. 2009. Budidaya Jamur.Jakarta. Agromesia. Pasaribu. dkk. 2002. Aneka Jamur Unggulan Yang Menembus Pasar.Jakarta. Grasindo.

Statistik (2016). Sumatera Barat dalam angka. Badan Pencatatan Statistik (BPS). Sumatera Barat.

Wintoko, B., 2012, Sukses Wirausaha Batako dan Paving Block, Pekanbaru : Pustaka Baru Press. 